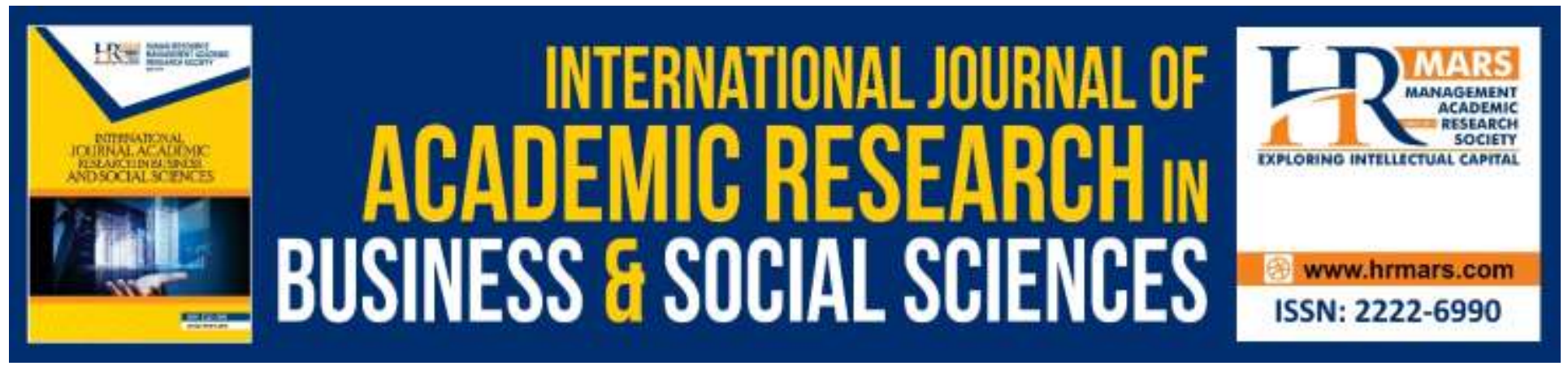

\title{
The Differences in Tendency of Aggressive Behaviour, Emotional Intelligence and Antisocial Personality between Gender and between Family System among Undergraduate University Students Lahore, Pakistan
}

Imdad Rabi, Ma'rof Bin Redzuan, Haslinda Abdullah, Hanina Halimatusaadiah Hamsan

To Link this Article: http://dx.doi.org/10.6007/IJARBSS/v8-i8/4442

DOI: $10.6007 /$ IJARBSS/v8-i8/4442

Received: 13 July 2018, Revised: 29 July 2018, Accepted: 09 August 2018

Published Online: 24 August 2018

In-Text Citation: (Rabi, Redzuan, Abdullah, \& Hamsan, 2018)

To Cite this Article: Rabi, I., Redzuan, M. Bin, Abdullah, H., \& Hamsan, H. H. (2018). The Differences in Tendency of Aggressive Behaviour, Emotional Intelligence and Antisocial Personality between Gender and between Family System among Undergraduate University Students Lahore, Pakistan. International Journal of Academic Research in Business and Social Sciences, 8(8), 87-99.

Copyright: (C) 2018 The Author(s)

Published by Human Resource Management Academic Research Society (www.hrmars.com)

This article is published under the Creative Commons Attribution (CC BY 4.0) license. Anyone may reproduce, distribute, translate and create derivative works of this article (for both commercial and non-commercial purposes), subject to full attribution to the original publication and authors. The full terms of this license may be seen

at: $\underline{\text { http://creativecommons.org/licences/by/4.0/legalcode }}$

Vol. 8, No. 8, August 2018, Pg. 87 - 99

http://hrmars.com/index.php/pages/detail/IJARBSS

JOURNAL HOMEPAGE

Full Terms \& Conditions of access and use can be found at http://hrmars.com/index.php/pages/detail/publication-ethics 


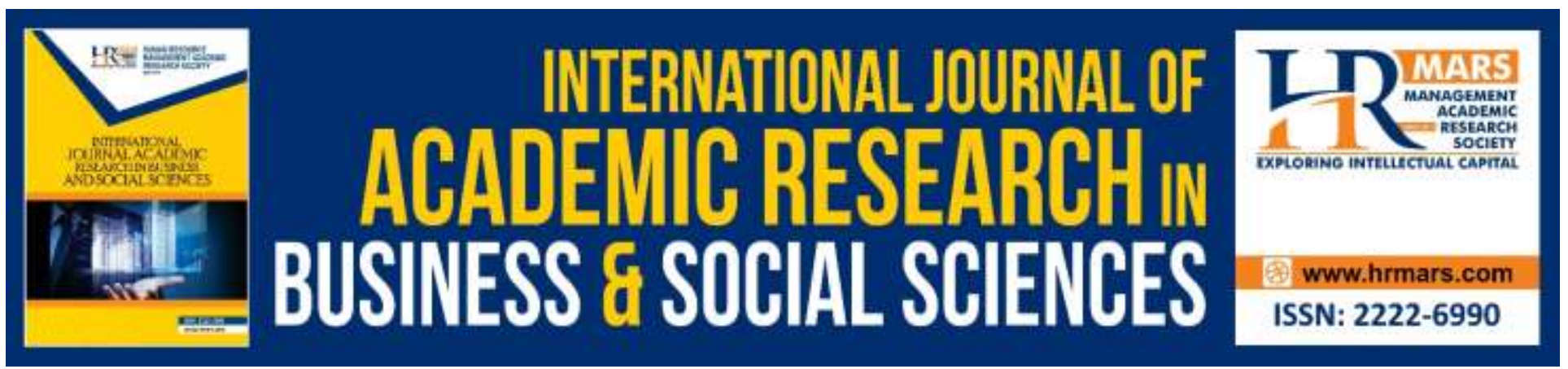

\title{
The Differences in Tendency of Aggressive Behaviour, Emotional Intelligence and Antisocial Personality between Gender and between Family System among Undergraduate University Students Lahore, Pakistan
}

\author{
Imdad Rabi \\ Department of Social and Development Sciences, Faculty of Human Ecology, University Putra \\ Malaysia \\ Dr. Ma'rof Bin Redzuan, Dr. Haslinda Abdullah \\ Associate Prof., Department of Social and Development Sciences, University Putra Malaysia \\ Dr. Hanina Halimatusaadiah Hamsan \\ Associate Prof., Department of Social and Development Sciences, University Putra Malaysia
}

\begin{abstract}
In the study independent Samples t-test was used to identifying difference in tendency of aggressive behavior, antisocial personality and emotional intelligence between gender and family system groups. The finding indicated that no significant difference in antisocial personality, emotional intelligence and tendency of aggressive behavior between genders. The findings indicated that students from nuclear families showed a higher tendency of aggressive behavior than those from joint families. Similarly students from nuclear families showed higher antisocial personality than those from joint families. In addition students from joint families were found to have higher emotional intelligence than students from nuclear families.
\end{abstract}

\section{Introduction}

The tendency of aggressive behavior among students is a common phenomenon throughout the world. Aggression is behavior with the sole purpose or function to injure physically or psychologically (Coleman, 2003). Aggressive behavior is an emotional response made on purpose for the sake of damaging or destroying other things or person (Kim and Hamann, 2007).

Aggressive behavior literally has a latin meaning ad "to" and gradus meaning "a step". It is used to mean a negative and unwanted human behavior. It is assertiveness gone too far (Hawley and Vaughn, 
2003; Smith, 2007). As early as the 1920, the concept of aggressive behavior has been around (Frodi, Macaulay and Thorne, 1977).

Young people in Pakistan can regularly be involved with violent, aggressive and antisocial behavior in universities and public spaces and roads. Thus, the main focus of this study is to consider why they behave like this. This kind of violence has become a serious social problem in Pakistan. The news can often report daily acts of violence which cause fear in the public living in cities. Several factors have become cultural norms such as revenge, jealousy, social climbing, and frustration due to the absence of social justice. The aggression amongst students can be one of two types physical includes pushing, hitting, slapping, biting, kicking, hair-pulling, stabbing, shooting and rape. The verbal aggression can include verbally threatening and intimidating others. It can include name-calling and teasing others. A previous study revealed that there are several factors that contribute to aggression including social, cultural, psychological, economical and educational. Each of these factors affects our behavior in covert or overt ways (Mushtaq and Kayani, 2013).

It has been argued that if children in dysfunctional families grow up in cohesive societies they have a greater likelihood to be able to defend against negative experiences. Therefore, if children are living in joint families they may be able to defend against traumatic experiences (Paris, 1996a). According to Archer and Coyne (2005) and Hess and Hagen (2006) the propensity of aggressive behavior is restricted in various ways for boys and girls in chosen surroundings. Aggressive behavior varies in boys and girls who are linked to those dangers which are faced by the girls which are greater than boys (Fagan, van Horn, Hawkins and Arthur, 2007). On the other hand researchers said that in reality, the inclination of aggressive behavior in girls is equal to boys as well (Sivarajasingam, Morgan, Shephered and Matthews, 2009; Najman et al., 2009).

\section{Literature Review}

Psychology, psychiatry, criminology and developmental psychology clearly have debated that in some societies, the number of boys who are inclined towards aggressive behavior is greater than girls (Baillargeon et al., 2007). It is known clearly that girls like to be involved in group aggressive behavior and in this way they become the victim of aggressive behavior as well (Crick, Ostrov and Kawabata, 2007). In addition Van Lier, Vitaro and Eisner (2007) studied gender tendency of aggressive behavior differences in school children and found that there was none. Research in rural communities also found that large, joint families also protect children against tendency of aggressive behavior if they are cohesive (Santangelo et al., 1994). However, Robins, Tipp and Przybeck, (1991) argue that the trend is that more women are now entering the criminal justice system. The reason for this increase is not confirmed. Evidence shows that more men are diagnosed with APD than women. Normally the male rate is seven times higher than females. Other academics believe that distant relatives in collectivist societies can act as role models and support individuals (Bhugra and Bhui, 2011). This finding is inconsistent with the research by Morand, (1999) who found a positive relationship between emotional intelligence and family size. However, it is consistent with the study by Cherian (1990) and Blake (1989) who found a negative effect. This means that there was a decrease in emotional intelligence with an increase in family size. The researchers argued that this maybe because children had a lesser interaction with the family elder. The children from nuclear families had lower emotional intelligence and less community focused values than children from joint families (Giri, 2015). There is a difference in the emotional needs fulfillment of children in joint and nuclear families. The results show that young people from the joint families are more emotionally satisfied (Tewari and Suryawanshi, 2015). 
Children in a nuclear family are totally dependent on their parents for meeting of their emotional needs. In most families parents do not know about child psychology and therefore do not meet their emotional needs. It has been argued that there is plenty of information about child upbringing, however most parents have not read this (Flory et al., 2007). Raths (1972) added that when children's emotional needs are not met they become frustrated and it is more difficult for them to study. In addition they develop a tendency of aggressive behavior, mental illnesses, withdrawal and compulsive behavior. Therefore, it can be said that the joint family system in Pakistan is better than nuclear family system to fulfill the emotional needs of growing adolescents.

Liu and Kaplan (2004) gave their verdict that boys are taught to be aggressive, strong and muscular and skilled enough to guard themselves. It can be said that aggression fits in with society's notion of masculinity. Carney (2008) inferred that when aggression happens in girls, it can include excluding or avoiding others, spreading gossip, verbal criticism and making fun of others are included in relational aggression. In social psychology the word gender infers how a person behaves. When we want to know the different components and aspects of behavior then gender plays a very important role. It is observed that boys are more inclined to be aggressive than girls (Bingham, Raymond; Shope, Jean and Raghunarhan, 2006; Archer and Coyne, 2005).

Males and females face physical and indirect harassment as a result of aggressive behavior, although only physical molestation seems like real aggressive behavior (Hoglund, 2007). Likewise, Rose and Rudolph (2006) and Underwood (2007) debated that if girls give a lot of importance to social bonds; then they would be more sensitive to social fighting, therefore indirect victimization is more distressful for them. Furthermore, boys and girls who have been exploited as a result of aggressive behavior are at risk of and inclined to be entangled in aggressive behavior (Card and Hodges, 2008; Waasdrop and Bradshaw, 2011). The inclination to be engaged in aggressive behavior was observed to be a role of boys and girls, for aggressive behavior like rumor spreading, neglecting and disdaining friend, stealing the things in possession of class fellows and exposing secrets in front of public. Aggression if found in students either girls or boys, has adverse effects for them (Storch and Ledley, 2005; Underwood, 2007). The inclination towards aggressive behavior of boys and girls is due to attachment problems (Pepler, Jiang, Craing and Connolly, 2008; Rodkin and Berger, 2008). There are several factors which are the main reasons for boys and girls inclination towards aggressive behavior in their lives such as poor relations and a poor relationship with their school (Hamel and Nicholls, 2007).

Champion and Clay (2007) came to an interesting conclusion that girls are more likely to respond to aggressive behavior and they find ways to improve the conditions to be involved in aggressive behavior and they justify their aggressive acts as being essential or excusable.

Individuals between 18 to 30 years of age have a high tendency of aggressive behavior (Archer, 2004). The Bureau of statistics in Australia has given the findings of it's research, in which it is stated that the school children aged 15 to 19 and 20 to 24 years have been found indulging in taking alcohol which is also a major cause of increase in aggressive behavior.

There are many differences between the genders in terms of their emotional intelligence (Katyal and Awasthi, 2005). However, Goleman (1995) stated that men and women are better in different aspects of emotional intelligence. Men who have high El have a good social standing, are happy and extroverted. They also have little fear and worry about failure. They are people that can take on responsibility, commit to a cause and are caring in their relationships. They are relaxed and content in their life and in their social life. He also argued that women with high emotional intelligence are 
self-aware, relate well with others, and have a higher sense of social responsibility than men. Men are more able to deal with immediate stressful issues (Stein et al., 2009).

A study by Hall (2000) called "sexuality and emotion" came to the conclusion that both genders have differences in the learning process of emotional management. Hall argued that parents emphasize the expression of feelings to their daughters rather than their sons. The girls are quite skillful in being able to pick up language and make use of words. The sons have not had the same emphasis on emotions therefore, they have less awareness about their own and other people's feelings (Hall et al., 2000).

A random sample of 150 students was used to study gender differences and El by Katyal and Awasthi (2005). They collected data using the standardized 'El scale'. The results showed that the entire sample had good El. Females had slightly higher El than the males. However, as the difference was only 0.10 , it cannot be conclusively said that females have a much higher El than males. The findings just suggest a trend.

Using trait El measures no difference was found between the genders. However, when a different measure for El was used than females scored higher than men on certain aspects. These aspects were being able to pick up and express emotions and also being able to gather emotions in thought. Psychological educational research has found that there is a link between gender and El but what that is has not been firmly cleared. Some studies show that there are noteworthy gender differences in El however other studies refute this. Common literature gives the suggestion that males and females have different styles when it comes to El (Katyal and Awasthi, 2005).

Emotional intelligence is found the same in both males and females. It is a common belief that males are less emotionally intelligent as compared to females but the important thing is that both the males and females have differences in the elements of emotional intelligence. However, some studies evidence that males are less emotionally intelligent than females (Wing and Love, 2001; Singh, 2007). It is evident that females should be more emotionally intelligent than males because they have more emotional and intimate relationships (Duckelt and Raffalli, 1989). Sandhu and Mehrotra (1999) support these findings by claiming that society is responsible for this because society treats both sexes in different ways. A study by Tapia and Marsh (1999) it was found that girls got higher scores than boys in traits such as empathy, social responsibility and interpersonal relationships. They were also found to be more sensitive towards their families and friends. The studies make the point that these traits allow girls to develop greater emotional intelligence than boys.

\section{Research Methodology}

In this section, an endeavour is made to explain how information is starting to be picked up from the area. Considering the nature of the survey, quantitative method seems to be relevant. Consequently the primary concern of this section a research plan, brief history of the subject region, description of the population, sample and sampling techniques, accumulation, and method of data analysis.

\section{Research Design}

Research designs are strategies and procedures for research that guide the decisions from broad assumptions to detailed method (Creswell, 2009). The quantitative approach is used in this study using survey design. According to Creswell (2013), the quantitative study is the investigation of human social problems based on testing of theory, composed of variables which need to be measured with numbers and examined with statistical methods in order to reach a logical conclusion, in order to assure weather expected prediction of theory hold true or not. The Survey design was preferred 
here due to various benefits including: it is easy to administer, it is low cost/inexpensive, it is able to cover high representativeness, it is statistically significant, observer subjectivity is reduced and results are precise. A survey is a better source for primary data collection than the observation method in social and behavioral sciences (Creswell, 2013). Due to the difficulty of observing a large population directly a survey method should be utilized. This allows original primary data from a large population to be collected (Babbie, 1998; 2001). Survey research design has been chosen in this study to collect data. Using survey design the data can be collected fast and it can be analyzed to understand the relationship between variables (Johnson, 2001; Johnson and Christensen, 2008).

A survey design is useful for gauging public opinions on any social issues (Creswell, 2013). It is also used to define the natural surroundings highlighting the societal realities (Cohen and Manion, 1980; Cohen et al., 2013). Therefore, a survey design was used for this research in Lahore, Pakistan. Surveys are used in a research methodology to collect data from a target population or a sample from that population. The questionnaire is used as the survey instrument (Robson, 1993). Following on from this, the survey design was used in this study under descriptive and inferential statistics research. Descriptive research is the right way to harness people's perceptions of social issues and social facts. The descriptive research design is selected because primary data through survey is required besides the secondary data. Therefore, the survey method was chosen because it is cost-effective, and time effective method of data analysis.

\section{Location of the Study}

The study was carried out in Lahore, the second largest city of Pakistan with 10 Tehsil/District educational regions. The city of Lahore had a population of approximately 7 million in 2016 (PBS, 2017). Lahore city is said to be the heart of Pakistan. The native language of the city is Punjabi but most people speak Urdu. Lahore was chosen as the study location based on the following considerations: (1) It is a large, central cosmopolitan city that is located in the middle of Pakistan. (2) Lahore has more colleges and universities than any other city in the country. Therefore, it is known as Pakistan's education capital. (3) Lahore was chosen for this study because Lahore has immigrants from different villages and smaller cities that may related to behavioral problems. (4) According to Dawn News, (2017) Lahore has the highest rate of problem behavior such as aggression, and antisocial behavior problems in the country compared to other cities.

\section{Population of the Study}

Population means all the members of a defined group or class. The target population is defined as the overall group of people that the findings of the study can be generalized to (Portney and Watkins, 2000). The target population of this study is the undergraduate university students who studied in the districts of Lahore, Pakistan. Lahore has 10 districts (Figure 3-2) and consists of 40,000 university students (Lahore Ministry of Education, 2014).

The following are the basic criteria in the selection of the respondents:

1. The respondents must be Pakistani citizens.

2. The respondents must be full time government university students.

3. The respondent's age is $18-23$ years old who are undergraduate students. 
INTERNATIONAL JOURNAL OF ACADEMIC RESEARCH IN BUSINESS AND SOCIAL SCIENCES Vol. 8, No. 8, August 2018, E-ISSN: 2222-6990 @ 2018 HRMARS

\section{Sample Size of the Study}

According to Krejcie and Morgan's table (1970), for a population of 40,000 a sample size of 380 is adequate. Cohen (1998) focused on reducing bias in a sample. This can be done by using a representative sample of the population rather than using a larger but biased population. Rubin and Babbie (2005) also explained that selecting samples to make generalizations in a quantitative study is acceptable rather than having to use a large sample. There are various factors involved with a sample size including time, cost, stress, resources, administration support or the number of researchers (Borg and Gall, 1979; Cohen et al., 2013). The maximum sample size for this study was 450. However, due to some issues in the data collection phase such as missing data, the sample size was lowered to 380 participants. This is supported by Sekaran (1983) who stated that a sample size of between 350 to 500 is effective. In addition the guide for sample size is: 50 is very poor, 100 is poor, 200 is fair, 300 is good, 500 is very good and 1000 is excellent (Tabachnick and Fidell, 1996). Following this sample size guide, in this study the researcher used 380 respondents as the sample size of the study.

\section{Sampling Process}

In this study the multistage cluster sampling approach was used to identify potential respondents. The multistage cluster sampling was constructed by taking a series of simple random samples in stages. Firstly, the geographical distribution of the universities in Lahore provided by the Ministry of Education was divided into five geographical regions (North, West, East, South, and Centre).

Each region consisted of various districts namely: North (district 6 and district 4), West (district 1 and district 10), East (district 9 and district 8), South (district 5 and district 7) and Centre (district 3 and district 2) of Lahore. Next, one educational district was randomly chosen from each geographical region. Accordingly to the sampling procedure, a total of 4 universities were randomly selected in Lahore. Since it was not possible to gain access to every student in the districts of Lahore; some portion of the target population was identified randomly.

For the sampling of this study, the researcher obtained official permission from the Ministry of Education in Lahore for four districts including district number one from west of the city, district number seven from south region of city, district three from the central, district four from north region of Lahore city and one university was chosen from each selected district.

\section{Data Analysis}

\section{Gender and Family System Difference in Tendency of Aggressive Behavior}

Table 4.1 : Independent Sample t - test of Gender and Family System Groups on Aggressive Behavior

\begin{tabular}{lcccccc}
\hline Variable & $\boldsymbol{N}$ & Mean & SD & Df & $\boldsymbol{T}$ & $\boldsymbol{P}$ \\
\hline Gender & & & & & & \\
$\quad$ Male & 202 & 3.75 & 1.40 & 378 & .252 & .801 \\
$\quad$ Female & 178 & 3.71 & 1.31 & & & \\
$\begin{array}{l}\text { Family System } \\
\quad \text { Joint }\end{array}$ & 136 & 3.62 & 1.33 & 378 & 2.044 & .042 \\
$\quad$ Nuclear & 244 & 3.91 & 1.32 & & & \\
\hline \hline
\end{tabular}


INTERNATIONAL JOURNAL OF ACADEMIC RESEARCH IN BUSINESS AND SOCIAL SCIENCES Vol. 8, No. 8, August 2018, E-ISSN: 2222-6990 @ 2018 HRMARS

The finding in Table 4.1 illustrated that, there is no significant difference in tendency of aggressive behavior between male $(\mathrm{M}=3.75, \mathrm{SD}=1.40)$ and female $(\mathrm{M}=3.71, \mathrm{SD}=1.31), \mathrm{t}(378)=.252, p=.801$. This finding is in agreement with Landsford et al., (2012) who discovered that males and females have very similar rates of tendency of aggressive behavior. It has been argued that both genders are similar in the rate of tendency of aggressive behavior in urban schools rather than in rural schools. In addition tendency of aggressive behavior also depends on the interaction between boys and girls (Ostrov and Houston, 2008). Plenty of academics have argued that the tendency of aggressive behavior of both genders is the same (Moffitt, Caspi, Harrington and Milne, 2002; Pepler et al., 2006).

An independent samples $\mathrm{t}$ - test was performed to compare the difference between joint family and nuclear family on aggressive behavior. The result in Table 4.1 shows a significant difference in tendency of aggressive behavior between joint family $(M=3.62, S D=1.33)$ and nuclear family $(M=$ 3.91, $\mathrm{SD}=1.32), \mathrm{t}{ }_{(378)}=2.044, p=.042$. The result clearly indicates that, the mean score for joint family was lower than nuclear family. This also means that respondents from joint family were less aggrieved in behavior than from nuclear family.

Gender and Family System Difference in Antisocial Personality

Table 4.2: Independent Sample t - test of Gender and Family System Groups on Antisocial Personality

\begin{tabular}{lcccccc}
\hline \hline Variable & $\boldsymbol{N}$ & Mean & SD & Df & $\boldsymbol{T}$ & $\boldsymbol{P}$ \\
\hline Gender & & & & & & \\
$\quad$ Male & 202 & 4.01 & 1.12 & 378 & -.737 & .462 \\
$\quad$ Female & 178 & 4.10 & 1.06 & & & \\
Family System & & & & & & \\
$\quad$ Joint & 136 & 3.97 & 1.09 & 378 & 2.780 & .006 \\
$\quad$ Nuclear & 244 & 4.28 & 1.03 & & & \\
\hline \hline
\end{tabular}

The analysis of mean difference in Table 4.2 shows that, there is no significant difference in antisocial personality between male $(M=4.01, S D=1.12)$ and female $(M=4.10, S D=1.06), t_{(378)}=-.737, p=.462$. Previous studies gave different opinions about whether or not there are differences between the genders and antisocial personality. Some academics state that different genders do have different levels of antisocial personality. This is because women display ASPD after a higher loading of risk factors compared to men (Yang and Diefendorff, 2009). Commonly it is considered that women are less antisocial than men as they commit fewer crimes than men (Giordano and Cerkovich, 1997).

The result of independent samples $t$ - test in Table 4.2 indicates that, there is a significant difference in antisocial personality between students from joint family $(M=3.97, S D=1.09)$ and students from nuclear family $(M=4.28, S D=1.03), t{ }_{(378)}=2.780, p=.006$. The result shows that, respondents from nuclear family have demonstrated more antisocial personality than those from joint family. This finding is in line with research which found that cohesive families show less antisocial personality. Cohesive families positively correlate with societies that have a low prevalence of antisocial personality (Paris, 1996). It has been found that lower rates of ASPD is found in societies that are cohesive socially, this makes antisocial pathology less likely. Academics think that the strong notions of shame and dishonor to the family are strong deterrents (Paris, 1996b). 
INTERNATIONAL JOURNAL OF ACADEMIC RESEARCH IN BUSINESS AND SOCIAL SCIENCES

Vol. 8, No. 8, August 2018, E-ISSN: 2222-6990 @ 2018 HRMARS

\section{Gender and Family System Difference in Emotional Intelligence}

Table 4.3: Independent Sample $t$ - test of Gender and Family System Groups on Emotional Intelligence

\begin{tabular}{lcccccc}
\hline \hline Variable & $\boldsymbol{N}$ & Mean & SD & Df & $\boldsymbol{T}$ & $\boldsymbol{P}$ \\
\hline Gender & & & & & & \\
$\quad$ Male & 202 & 3.12 & .98 & 378 & -.448 & .654 \\
$\quad$ Female & 178 & 3.16 & .91 & & & \\
Family System & & & & & & \\
$\quad$ Joint & 136 & 3.31 & .86 & 378 & 2.684 & .008 \\
$\quad$ Nuclear & 244 & 3.06 & .92 & & & \\
& & & & & & \\
\hline \hline
\end{tabular}

The finding in Table 4.3 shows that, there is no significant difference in emotional intelligence between male students $(M=3.12, S D=.98)$ and female students $(M=3.16, S D=.91), t{ }_{(378)}=-.448$, $p=.654$. This finding is in line with the views of Goleman (1998) who stated that there is no difference between males and females level of emotional intelligence. He argued that everyone is an individual with different strengths and weaknesses. There are actually more similarities between the genders than there are differences. When the profiles of both genders are averaged out the emotional intelligence scores are the same.

The independent sample $t$ - test result in Table 4.3 shows a significant difference in emotional intelligence between students from joint family $(M=3.31, S D=.86)$ and students from nuclear family $(\mathrm{M}=3.06, \mathrm{SD}=.92), \mathrm{t}{ }_{(378)}=2.684, p=.008$. The result shows that, the mean score for joint family was greater than mean score for nuclear family. This also indicates that, students from joint family have more emotional intelligence than students from nuclear family. This finding is in line with other research that evidenced a higher level of social maturity of people from joint families rather than nuclear families. This was because respondents from joint families had stronger interpersonal skills and were more socially adequate than respondents from nuclear families. Respondents from joint families also had higher emotional stability, emotional progression, social adjustment, personality integration and independence (Kamla and Raj, 2014).

\section{Conclusion}

The finding indicated that no significant difference in antisocial personality, emotional intelligence and tendency of aggressive behavior among gender. The present findings are consistent with the findings of several past studies. Landsford (2012) discovered that males and females have very similar rates of tendency of aggressive behavior. Goleman (1998) stated that there is no difference between males and females level of emotional intelligence. Women are less antisocial than men as they commit fewer crimes than men (Giordano and Cerkovich, 1997).

The findings indicate that students from nuclear families showed a higher tendency of aggressive behavior than those from joint families. Similarly students from nuclear family showed higher antisocial personality than those from joint families. In addition students from joint families were found to have higher emotional intelligence than students from nuclear families. Kaut and Kaur (2011) found that children from joint families were less aggressive than children living in nuclear families. Research by Kamla and Raj (2014) showed that individuals from joint families also had higher emotional stability, emotional progression, social adjustment, personality integration and 
INTERNATIONAL JOURNAL OF ACADEMIC RESEARCH IN BUSINESS AND SOCIAL SCIENCES

Vol. 8, No. 8, August 2018, E-ISSN: 2222-6990 @ 2018 HRMARS

independence. Cohesive families positively correlate with societies that have a low prevalence of antisocial personality (Paris, 1996).

\section{Acknowledgement}

Faculty of Human Ecology

University Putra Malaysia

\section{Corresponding Author}

Imdad Rabi

Faculty of Human Ecology

University Putra Malaysia

Dr.imdadrabi@gmail.com

\section{References}

Archer, J. (2004). Sex differences in aggression in real-world settings: a meta-analytic review. Review of general Psychology, 8(4), 291.

Archer, J., and Coyne, S. M. (2005). An integrated review of indirect, relational, and social aggression. Personality and Social Psychology Review, 9(3), 212-230.

Babbie, E. (1998). The Practice of Social Research 8th edition (Wadsworth, Belmont, CA).

Babbie, E. (2001). The practice of social research. Belmont, CA: Wadsworth/Thomson Learning.

Baillargeon, R. H., Zoccolillo, M., Keenan, K., Côté, S., Pérusse, D., Wu, H. X., ... and Tremblay, R. E. (2007). Gender differences in physical aggression: A prospective population-based survey of children before and after 2 years of age. Developmental psychology, 43(1), 13.

Bhugra, D., and Bhui, K. (Eds.). (2011). Textbook of cultural psychiatry. Cambridge University Press.

Bingham, C. R., Shope, J. T., and Raghunathan, T. (2006). Patterns of traffic offenses from adolescent licensure into early young adulthood. Journal of Adolescent Health, 39(1), 35-42.

Blake, J. (1989). Family size and achievement (Vol. 3). Univ of California Press.

Borg, W. R., and Gall, M. D. (1979). An introduction to educational research.

Card, N. A., and Hodges, E. V. (2008). Peer victimization among schoolchildren: Correlations, causes, consequences, and considerations in assessment and intervention. School psychology quarterly, 23(4), 451.

Carney, J. (2008). Perceptions of bullying and associated trauma during dolescence. Professional School Counseling, 11(3), 179-188.

Champion, K. M., and Clay, D. L. (2007). Individual differences in responses to provocation and frequent victimization by peers. Child Psychiatry and Human Development, 37(3), 205-220.

Cherian, V. I. (1990). Birth order and academic achievement of children in Transkei. Psychological Reports, 66(1), 19-24.

Cohen, L. (81). en Manion, L.(1980) Research Methods in Education. London and New.

Cohen, L., Manion, L., and Morrison, K. (2013). Research methods in education. Routledge.

Cohen, P. N. (1998). Black concentration effects on black-white and gender inequality: Multilevel analysis for US metropolitan areas. Social Forces, 77(1), 207-229.

Coleman, V. E. (2003). Treating the lesbian batterer: Theoretical and clinical considerations A contemporary psychoanalytic perspective. Journal of aggression, maltreatment and trauma, 7(1-2), 159-205. 
INTERNATIONAL JOURNAL OF ACADEMIC RESEARCH IN BUSINESS AND SOCIAL SCIENCES

Vol. 8, No. 8, August 2018, E-ISSN: 2222-6990 @ 2018 HRMARS

Creswell, J. W. (2013). Research design: Qualitative, quantitative, and mixed methods approaches. Sage publications.

Crick, N. R., Ostrov, J. M., and Kawabata, Y. (2007). Relational aggression and gender: An overview.

Down News. (2017) Violence-related Fatalities in Balochistan, Punjab increased in 2016. [Available] at. https://www.dawn.com/news/1306301.

Duckelt, E., and Raffalli, M. (1989). Taking care, maintaining the self and the home in adolescents. Journal of Youth and Adolescence, 18(6), 549.

ear_Family(2015)

Fagan, A. A., Van Horn, M. L., Hawkins, J. D., and Arthur, M. W. (2007). Gender similarities and differences in the association between risk and protective factors and self-reported serious delinquency. Prevention Science, 8(2), 115-124.

Frodi, A., Macaulay, J., \& Thorne, P. R. (1977). Are Women Less Aggressive Than Men?. Psychologicai Bulletin, 84(4), 654.

Giordano, P. C., and Cernkovich, S. A. (1997). Gender and antisocial behavior. Giri,https://www.researchgate.net/publication/270957439_Joint_Family_and_Nucl

Goleman, D. (1995). Emotional intelligence: Why it can matter more than IQ.

Goleman, D. (1998). Working with emotional intelligence. Bantam.

Hall, D. K. (2000). "Complex" posttraumatic stress disorder/disorders of extreme stress (CP/DES) in sexually abused children: An exploratory study. Journal of Child Sexual Abuse, 8(4), 51-71.

Hall, J. A., Carter, J. D., and Horgan, T. G. (2000). Gender differences in nonverbal communication of emotion. Gender and emotion: Social psychological perspectives, 97-117.

Hamel, J., and Nicholls, T. L. (2007). Perceptions of motives in intimate partner violence: Expressive versus coercive violence. Violence and Victims, 22(5), 563.

Hawley, P. H., and Vaughn, B. E. (2003). Aggression and adaptive functioning: The bright side to bad behavior. Merrill-Palmer Quarterly, 49(3), 239-242.

Hess, N. H., and Hagen, E. H. (2006). Sex differences in indirect aggression: Psychological evidence from young adults. Evolution and Human Behavior, 27(3), 231-245.

Hoglund, W. L. (2007). School functioning in early adolescence: Gender-linked responses to peer victimization. Journal of Educational Psychology, 99(4), 683.

Johnson, B. (2001). Toward a new classification of nonexperimental quantitative research. Educational Researcher, 30(2), 3-13.

Johnson, B., and Christensen, L. (2008). Educational research: Quantitative, qualitative, and mixed approaches. Sage.

Kamla, R. (2014) http://www.krepublishers.com/02-Journals/T-Anth/Anth-17-0-000-14-Web

Katyal, S., and Awasthi, E. (2005). Gender differences in emotional intelligence among adolescents of Chandigarh. Journal of Human Ecology, 17(2), 153-155.

Kim, S. H., and Hamann, S. (2007). Neural correlates of positive and negative emotion regulation. Journal of cognitive neuroscience, 19(5), 776-798.

Krahé, B. (2000). Heterosexual Aggression. The developmental social psychology of gender, 273.

Krejcie, R. V., and Morgan, D. W. (1970). Determining sample size for research activities. Educational and psychological measurement, 30(3), 607-610.

Lansford, J. E., Skinner, A. T., Sorbring, E., Giunta, L. D., Deater-Deckard, K., Dodge, K. A., ... and Uribe Tirado, L. M. (2012). Boys' and girls' relational and physical aggression in nine countries. Aggressive behavior, 38(4), 298-308. 
INTERNATIONAL JOURNAL OF ACADEMIC RESEARCH IN BUSINESS AND SOCIAL SCIENCES

Vol. 8, No. 8, August 2018, E-ISSN: 2222-6990 @ 2018 HRMARS

Liu, R. X., and Kaplan, H. B. (2004). Role stress and aggression among young adults: The moderating influences of gender and adolescent aggression. Social psychology quarterly, 67(1), 88-102.

Moffitt, T. E., Caspi, A., Harrington, H., and Milne, B. J. (2002). Males on the life-course-persistent and adolescence-limited antisocial pathways: Follow-up at age 26 years. Development and psychopathology, 14(1), 179-207.

Morand, D. A. (1999). Family size and intelligence revisited: The role of emotional intelligence. Psychological reports, 84(2), 643-649.

Mushtaq, M., and Kayani, M. M. (2013). Exploring the factors causing aggression and violence among students and its impact on our social attitude. Educational Research International, 2, 10-18.

Najman, J. M., Hayatbakhsh, M. R., McGee, T. R., Bor, W., O'Callaghan, M. J., and Williams, G. M. (2009). The impact of puberty on aggression/delinquency: Adolescence to young adulthood. Australian and New Zealand Journal of Criminology, 42(3), 369-386.

Ostrov, J. M., and Houston, R. J. (2008). The utility of forms and functions of aggression in emerging adulthood: Association with personality disorder symptomatology. Journal of Youth and Adolescence, 37(9), 1147-1158.

Pakistan Bureau of Statistics. (2017). http://www.pbs.gov.pk/

Paris, J. (1996). Antisocial personality disorder: a biopsychosocial model. The Canadian Journal of Psychiatry, 41(2), 75-80.

Pepler, D. J., Craig, W. M., Connolly, J. A., Yuile, A., McMaster, L., and Jiang, D. (2006). A developmental perspective on bullying. Aggressive behavior, 32(4), 376-384.

Pepler, D., Jiang, D., Craig, W., and Connolly, J. (2008). Developmental trajectories of bullying and associated factors. Child development, 79(2), 325-338.

Portney, L. G., and Watkins, M. P. (2000). Validity of measurements. Foundations of clinical research: Applications to practice, 2.

Raths, L. E. (1972). Meeting the needs of children: Creating trust and security. Merrill Publishing Company.

Robins, L. N., Tipp, J., and Przybeck, T. (1991). Antisocial personality. Psychiatric disorders in America, 258-290.

Robson, C. (1993). Real world research: A resource for social scientists and practitionersresearchers. Massachusetts: Blackwell Pushers.

Rodkin, P. C., and Berger, C. (2008). Who bullies whom? Social status asymmetries by victim gender. International Journal of Behavioral Development, 32(6), 473-485.

Rose, A. J., and Rudolph, K. D. (2006). A review of sex differences in peer relationship processes: potential trade-offs for the emotional and behavioral development of girls and boys. Psychological bulletin, 132(1), 98.

Rubin, A., \& Babbie, E. R. (2005). Research methods for social work . Belmont: Thomson Learning.

Sandhu, P., and Mehrotra, N. (1999). Time pattern of female students with special reference to leisure time activities. Indian Journal of Social Research, 40(4), 285-296.

Santangelo, S. L., Pauls, D. L., Goldstein, J. M., Faraone, S. V., Tsuang, M. T., and Leckman, J. F. (1994). Tourette's syndrome: what are the influences of gender and comorbid obsessive-compulsive disorder?. Journal of the American Academy of Child and Adolescent Psychiatry, 33(6), 795804.

Sekaran, U. (1983). Methodological and theoretical issues and advancements in cross-cultural research. Journal of international business studies, 14(2), 61-73. 
INTERNATIONAL JOURNAL OF ACADEMIC RESEARCH IN BUSINESS AND SOCIAL SCIENCES

Vol. 8, No. 8, August 2018, E-ISSN: 2222-6990 @ 2018 HRMARS

Singh, S. K. (2007). Emotional intelligence and organisational leadership: A gender study in Indian context. International Journal of Indian Culture and Business Management, 1(1-2), 48-63.

Sivarajasingam, V., Morgan, P., Matthews, K., Shepherd, J., and Walker, R. (2009). Trends in violence in England and Wales 2000-2004: an accident and emergency perspective. Injury, 40(8), 820825.

Smith, P. (2007). Why has aggression been thought of as maladaptive. Aggression and adaptation: The bright side to bad behavior, 65-83.

Stein, S. J., Papadogiannis, P., Yip, J. A., and Sitarenios, G. (2009). Emotional intelligence of leaders: A profile of top executives. Leadership and Organization Development Journal, 30(1), 87-101.

Storch, E. A., and Ledley, D. R. (2005). Peer victimization and psychosocial adjustment in children: Current knowledge and future directions. Clinical Pediatrics, 44(1), 29-38.

Tabachnick, B. G., and Fidell, L. S. (1996). Analysis of covariance. Using multivariate statistics, 8(1), 321-374.

Tapia, M., and Marsh II, G. E. (2006). The effects of sex and grade-point average on emotional intelligence. Psicothema, 18.

Tewari, P., and Suryawanshi, S. K. (2015). Emotional need fulfillment in adolescents of joint family and nuclear family: a comparative study. Online Journal of Multidisciplinary Research (OJMR), 1(1), 18-22.

Underwood. (2007). Friendship features and social exclusion: An observational study examining gender and social context. Merrill-Palmer Quarterly, 53(3), 412-438.

van Lier, P., Vitaro, F., and Eisner, M. (2007). Preventing aggressive and violent behavior: Using prevention programs to study the role of peer dynamics in maladjustment problems. European Journal on Criminal Policy and Research, 13(3-4), 277-296.

Waasdorp, T. E., and Bradshaw, C. P. (2011). Examining student responses to frequent bullying: a latent class approach. Journal of Educational Psychology, 103(2), 336.

Wing, E., and Love, G. D. (2001). Elective affinities and uninvited agonies: Mapping emotions with significant others onto health. Emotion, Social Relationships and Health Series in Affective Science.

Yang, J., and Diefendorff, J. M. (2009). The relations of daily counterproductive workplace behavior with emotions, situational antecedents, and personality moderators: A diary study in Hong Kong. Personnel Psychology, 62(2), 259-295. 